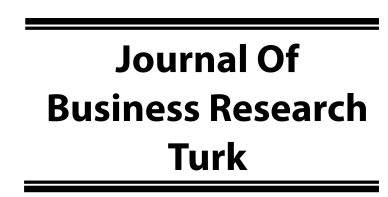

www.isarder.org

\title{
One Way Ticket-Route To Death: How Right Is To Promote As A Commercial Initiative?
}

\author{
Arzu Kılıçlar \\ Gazi University, Faculty of \\ Tourism, Department of Travel \\ Management and Tour Guiding, \\ 06830 Golbasi, Ankara, Turkey \\ orcid.org/0000-0002-3223-582X \\ karzu@gazi.edu.tr
}

Beyza Adıgüzel

Gazi University, Faculty of Tourism, Department of Tourism Management, 06830 Golbasi, Ankara, Turkey orcid.org/0000-0002-2932-1671 byzhtrnz@gmail.com

\author{
Fulden Nuray Küçükergin ${ }^{1}$ \\ Gazi University, Faculty of \\ Tourism, Department of Travel \\ Management and Tour Guiding, \\ 06830 Golbasi, Ankara, Turkey \\ orcid.org/0000-0002-0943-0467 \\ fuldengural@gazi.edu.tr
}

\author{
Bahadır İnanç Özkan \\ Gazi University \\ Social Sciences Institute \\ 06500 Besevler - Ankara, Turkey \\ orcid.org/0000-0002-7665-6765 \\ inancozkan@gmail.com
}

\author{
Seval Kurt \\ Gazi University, Faculty of \\ Tourism, Department of Tourism \\ Management, 06830 Golbasi, \\ Ankara, Turkey \\ orcid.org/0000-0002-9012-5522 \\ sevalkurt@gazi.edu.tr \\ Halil Can Aktuna \\ Gazi University, Faculty of \\ Tourism, Department of Travel \\ Management and Tour Guiding, \\ 06830 Golbasi, Ankara, Turkey \\ orcid.org/0000-0002-5930-2834 \\ aktunahalilcan@gmail.com
}

\begin{abstract}
In this study, it has been argued the efforts of combining the concept of euthanasia and assisted suicide in the last few years with the concept of tourism. This study aims to investigate the concepts of euthanasia/assisted suicide with their medical, legal and religious dimensions and how right it is to promote the practicing centers as commercial tourism initiatives. Initially, tourism and tourist concepts have been explained then medical and juristically embodiments and applications have been detailed. It is pointed that, in many countries euthanasia and assisted suicide is forbidden while Netherlands, Belgium, Luxembourg, United States of America, Canada and Colombia are the countries accepting euthanasia/assisted suicide. Switzerland has a unique place practicing euthanasia/assisted suicide although it is not accepted legally. Subsequently, religious point of view has been discussed and it has been clarified that euthanasia/assisted suicide and tourism concept cannot coexist.
\end{abstract}

Keywords: Euthanasia; (Physician) Assisted Suicide; Assisted Suicide/ Euthanasia Tourism; Assisted suicide businesses; Right-to-Die Organizations; VAE; PAS; AS.

\section{INTRODUCTION}

With the new discoveries and explorations made on the basis of the progress of science and technology, people whose living standards have changed have started to make more free decisions about their own lives. Especially in the context of person's desire to interpret the religious teachings personally, the moral concepts gradually began

\footnotetext{
${ }^{1}$ Corresponding Author
} 
to empty. Suicide has begun to increase, even though it is banned in almost all religions (World Health Organization, 2014).

Judging from the point of view of laws, suicide is not a crime which is seen as a personal act in many countries, but euthanasia carried out with the help of someone else is considered as a crime. Although there are countries that adopt euthanasia legallyNetherlands, Belgium - there are countries that do not legally accept, but actively applySwitzerland - and even countries that use this to make income. This encourages people to go to these countries for the application of euthanasia in countries where euthanasia is prohibited and creates a market. The fact that this practice involves intercountry travel and has led to begun to be examined under the tourism literature. At present, concepts of euthanasia and assisted suicide, which cannot be fully framed in the medical and legal literature, have been introduced as "euthanasia/assisted suicide tourism" by a documentary named "The Suicide Tourist" in 2007 (Ogden, Hamilton, and Whitcher, 2010, pp. 1; Zaritsyk, 2007) and then integrated into the literature by Huxtable in 2009, regardless of whether it is appropriate to tourism definition or not (Higginbotham, 2011, pp. 178; Huxtable, 2009).

Studies that have been made in various disciplines show that travelling for assisted suicide is getting higher year by year (Gauthier, Mausbach, Reisch and Bartsch, 2014). Gauthier et al. (2014) emphasized in their study that between the years 20082012 there were 611 cases which practiced to non-Swiss citizens who came from other countries.

In this study, the concepts of euthanasia and assisted suicide were examined with their medical, legal and religious dimensions via literature review. It has been discussed whether euthanasia can be evaluated as a tourism type.

\section{DISCUSSION OF WHAT IS WHAT?}

Tourism has a long history indeed. Many studies point out that the Sumerians' development of trade around $4000 \mathrm{BC}$ as the birth of travel (Cooper, 2013; Goeldner and Ritchie, 2009). Initially, the major motivation of travel is for trade. At a later period, besides trade, military and administrative purposes were also a motivation for travel, then religious festivals and pilgrimage came to the forefront (Cooper, 2013; Cooper and Hall, 2008). With years of evolving technology and transportation, travelling to long distances gets easier and motivation to travel have changed (eg. medical needs, congress participation etc.) (Crompton, 1979; Dann, 1977; Jang and Cai, 2002; Pearce and Caltabiano, 1983; Yuan and McDonald, 1990). One of the motivation of travelling one place to another place is euthanasia/assisted suicide in recent years. And this mobility is tried to be named as "euthanasia/assisted suicide tourism". This is really very controversial issue. In order to understand whether "euthanasia/assisted suicide mobility" is a tourism type, it is necessary to first examine the concept of tourism etymologically. Tourism, has started to be used in its present sense since early nineteenth century, is closely associated with the word "tour", which means circular movement around a central place or axis and returns to starting point is derived from the roots of Latin "tornare / tornus" and Greek "tornos". In modern English this concept has changed to mean "round-trip" (Gilbert, 1990, pp. 47; Hunt and Layne, 1991; Theobald, 2005, pp. 9).

The importance of "tour" expression has been emphasized throughout the years for defining the concept of tourism. Early definitions to late definitions, tourism is; "a phenomenon unique to modern time which is dependent on the people's increasing need 
for a change and relaxing, the wish of recognizing the beauties of nature and art and the belief that nature gives happiness to human beings and which helps nations and communities and intention to return within a few days, weeks or months approaching to each other thanks to the developments in commerce and industry and the communication and transportation tools' becoming excellent" (Cooper, 2013; Cooper and Hall, 2008; Gilbert, 2004; Leiper, 1990; Sicart, 2016; Urry, 1992, Urry and Larsen, 2001). In spite of various definitions, concepts and descriptions of tourism with the scope of geography, sociology, psychology, business and so on, to understand the tourist behavior as a consumer, the first economic description was made by Hermann von Schullern - Schrattenhofen, an economist. Schullern zu Schrattenhofen (1911) defined tourism as; "the set of all the phenomena, especially economic ones, produced by the arrival, stay, departure and returning of travelers in a certain commune, province or state and which, as a consequence, are directly linked to them". Modern tourism concept was made in 1942 by Walter Hunziker and Kurt Krapf during World War II. According to this definition tourism is; "the sum of the phenomena and relationships arising from the travel and stay of non-residents, insofar as they do not lead to permanent residence and are not connected with any earning activity" (Holloway, 1989; Hunziker \& Krapf, 1942; Jayapalan, 2001). Association of Scientific Experts in Tourism (AIEST) has added the concept of free time to this definition made in the 1970s. In 1976 The British Tourism Community has defined tourism as follows; "all of the activities were conducted outside the people's ordinary living environment" (Beaver, 2002). Tourism was defined in the World Tourism Organization's (WTO) Travel and Tourism Statistics Conference in Ottawa in 1991. According to this definition tourism; "comprises the activities of persons traveling to and staying in places outside their usual environment for not more than one consecutive year for leisure, business and other purposes" (WTO, 1995).

\section{Table 1. First tourism definitions of global organizations}

\begin{tabular}{|l|l|}
\hline $\begin{array}{l}\text { The International Union of } \\
\text { Official Travel } \\
1950\end{array}$ & $\begin{array}{l}\text { Added students on study tours as touristst. And 'international } \\
\text { excursionist' (an individual visiting another country for pleasure for less } \\
\text { than 24 hours) and 'transit travelers' (persons traveling through a country } \\
\text { without stopping en route). }\end{array}$ \\
\hline $\begin{array}{l}\text { UN Statistical Commission- } \\
\text { UNSC, } 1953\end{array}$ & Added by setting a maximum stay of six months. \\
\hline $\begin{array}{l}\text { The United Nations } \\
\text { Utatistical Commission- }\end{array}$ & $\begin{array}{l}\text { Endorsed the term 'tourist' and suggested dropping 'day visitor' in favor } \\
\text { of 'excursionist' for those staying less than } 24 \text { hours. also recommended } \\
\text { classifying 'transit travelers' as 'excursionists'. }\end{array}$ \\
\hline $\begin{array}{l}\text { Organisation for Economic } \\
\text { Co-operation and }\end{array}$ & $\begin{array}{l}\text { 'International tourist' as anyone visiting a country other than his/her } \\
\text { usual residence for more than 24 hours, excluding workers, migrants, } \\
\text { commuters, students, and travelers who did not stop while en route } \\
\text { through a country on their way to a third country. }\end{array}$ \\
\hline $\begin{array}{l}\text { United Nations World } \\
\text { Tourism Organization- }\end{array}$ & $\begin{array}{l}\text { These recommendations were ratified in 1978 at a conference with } \\
\text { representatives of the World Tourism Organization (UNWTO), the } \\
\text { UNConference onTrade and Development, the Conference of European } \\
\text { Statisticians, the East Caribbean Common Market, and the Caribbean } \\
\text { community. }\end{array}$ \\
\hline
\end{tabular}

Resource: Hall, Williams and Lew, 2004, pp. 27-29.

Academic fields, firms and governmental organizations dwell on three approaches to define of tourism concept as 'economic', 'technical' and 'holistic' (de Esteban, Cetin and Antonovica, 2015; Demen-Meier, 2005: 3; Leiper, 1979). The economic approaches 
emphasize tourism industry and business implications (supply side) and also can be criticized to ignore tourist, spatial and temporal elements. Technical approaches are preferred to test comparable statistics by defining tourist, monitoring the size, and characteristics and flow of tourist markets (demand side). Holistic approaches indicate interdisciplinary and multidisciplinary tourism regardless of distance, duration and purpose (Leiper, 1979). There are various ways of defining tourism and also tourism tends to adopt different approaches. It is more appropriate to take a systematic approach to tourism, which is composed of a set of units that have an established relationship among the complex interaction elements (Govers, Van Hecke and Cabus, 2008; Hall 2005; Hall and Müller, 2004; Leiper, 1979). Leiper (1979) was an early advocate of a systems approach towards tourism by using five elements: tourists, three geographical elements (generating region, transit route, and destination region), and a tourist industry. System approach allows to understand the overall process of tourism from both the demand and the supply side. According to Leiper (1979)

"... a new definition of tourism. It is the system involving the discretionary travel and temporary stay of persons away from their usual place of residence for one or more nights, excepting tours made for the primary purpose of earning remuneration from points a route. The elements of the system are tourists, generating regions, transit routes, destination regions and a tourist industry. These five elements are arranged in spatial and functional connections. Having the characteristics of an open system, the organization of five elements operates within broader environments: physical, cultural, social, economic, political, technological with which it interacts..." (pp.404).

\begin{tabular}{|c|c|c|}
\hline \multicolumn{3}{|c|}{ The Environment } \\
\hline $\begin{array}{l}\text { Generating region } \\
\text { (the permanent residence of } \\
\text { the tourist) } \\
\text { 1. Travel decision-making and } \\
\text { anticipation }\end{array}$ & $\begin{array}{c}\text { Transit region or route } \\
\text {-Transport links between the } \\
\text { source region and the } \\
\text { destination } \\
\text { 2. Travel to destination }\end{array}$ & $\begin{array}{l}\text { Destination (the temporary } \\
\text { residence of the tourist) }\end{array}$ \\
\hline $\begin{array}{l}\text { channels for the destination } \\
\text { 5. Recollection of the trip and } \\
\text { destination experiences and } \\
\text { influence on future tourism } \\
\text { decision-making }\end{array}$ & 4. Return home & $\begin{array}{l}\text { 3. Experiences at the destination } \\
\text {-Facilities and attractions }\end{array}$ \\
\hline
\end{tabular}

Fig 1. Tourism System, Adapted from Leiper (1979) and Cooper and Hall (2008, pp. 7,8, 10).

Tourism process begins at generating or source region (which is the permanent residence/usual environment of the tourist and the place where the journey begins and ends). Transit route is the path to reach his/her destination and to return home. Destination region is where tourists stay temporarily for tourism mobility.

Most accepted definitions go beyond the concept of tourism as a leisure or holiday activity to emphasize temporary short-term movement of people to destinations outside their normal environment and their activities. Also technical definitions are formulated for particular purposes, to include or exclude particular trips and visits, mainly by reference to purpose, time and distance criteria (Medlik, 2003, pp. vii). Tourism has prevented the emergence of a meaningful definition of universal acceptance of multidimensional directions and activities, and has led to the definition of a special purpose and a focus on a solution to the problem, unlike the system approach. 
(Goeldner and Ritchie, 2009, pp. 6). Latest definition of tourism by UNWTO is, "the activities of persons travelling to and staying in places outside their usual environment for not more than one consecutive year for leisure, business and other purposes," in 2016, (pp.50).

After reviewing origin of the word and concept of tourism, it is necessary to analyze the definition of tourist. Despite studies on the concept of tourism being made in the early 20th century, the emergence of the tourist word is based on the past. Travelers who traveled to continental Europe from Great Britain during 'Elizabeth I (1558-1603)' were called 'tourists' to be distinguished from locals in the countries where they were going and this action were called 'tour' (Libera, 1963). Despite the fact that the past is so much rooted, F.W. Ogilvie made the first definition in modern sense in 1933. According to this definition tourist is "who has spent most of a year at the place where he has been permanently resident and who has spent the money he has not earned in places where he has gone temporarily" (Ogilvie, 1933). According to Leiper's definition of tourist may be defined as "a person who makes a temporary tour at his / her own discretion, provided that he / she makes at least one night stay from his / her normal residence, except for travel made for the purpose of earning money" (Leiper, 1979). According to the recognition that the WTO had done in 1991, international tourists; "A visitor who travels to a country other than the country in which he / she is located, traveling for at least one night but not exceeding one year and participating in an activity paid by the tourist who visits the country" (WTO, 1995).

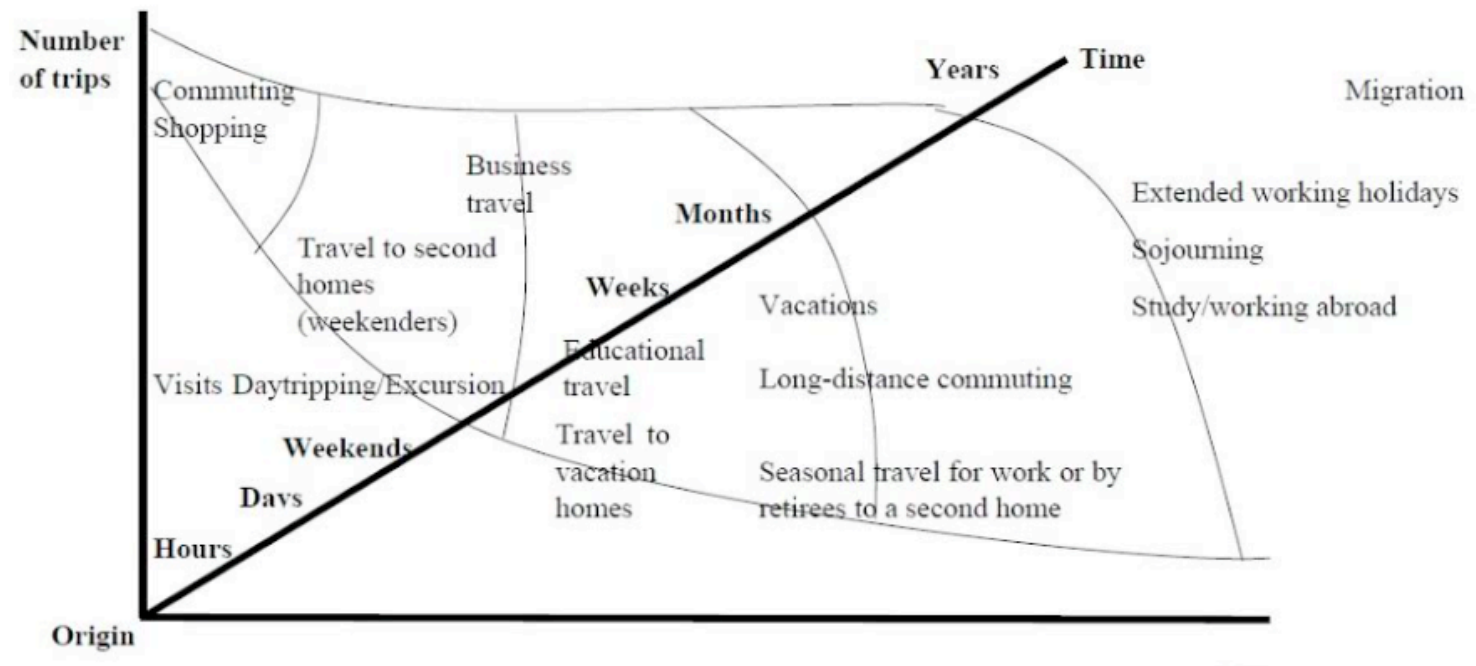

Fig. 2. Extent of temporary mobility in space and time

Resource: Hall, Williams and Lew, 2004:6.

Temporal mobility and length of stay are used as an important indicator in distinguishing tourists from other travelers in the context of space and time. The distance to the destination to be visited, the length of stay and return to residence are the determinants used in the definition of tourism and tourists (Hall, Williams and Lew, 2004: 6). Work on the definition of temporary mobility and circulation has increased in the definition of tourism (Bell and Ward 2000; O'Reilly, 2003; Williams and Hall 2000). The 'usual environment' concept is the most difficult and the most ambiguous to define, with the most important criterion used to distinguish tourists (Govers, Van Hecke and Cabus, 2008; Tuan, 1974). While not widespread in geography literature, 
space-time relations describe the nature of geography (Tuan, 1974). In this respect, geographers use tourism as a prerequisite for tourism mobility (Hall, Williams and Lew, 2004, pp. 5), while sociologists define spatial prism as a prerequisite for tourism mobility by distinguishing tourism from other travel types. Change in relation to the social environment in the context of 'hosts and guests' (Cohen, 1984). In this context, the conceptualization of tourism necessitates to be evaluated in terms of the relationship between time and place.

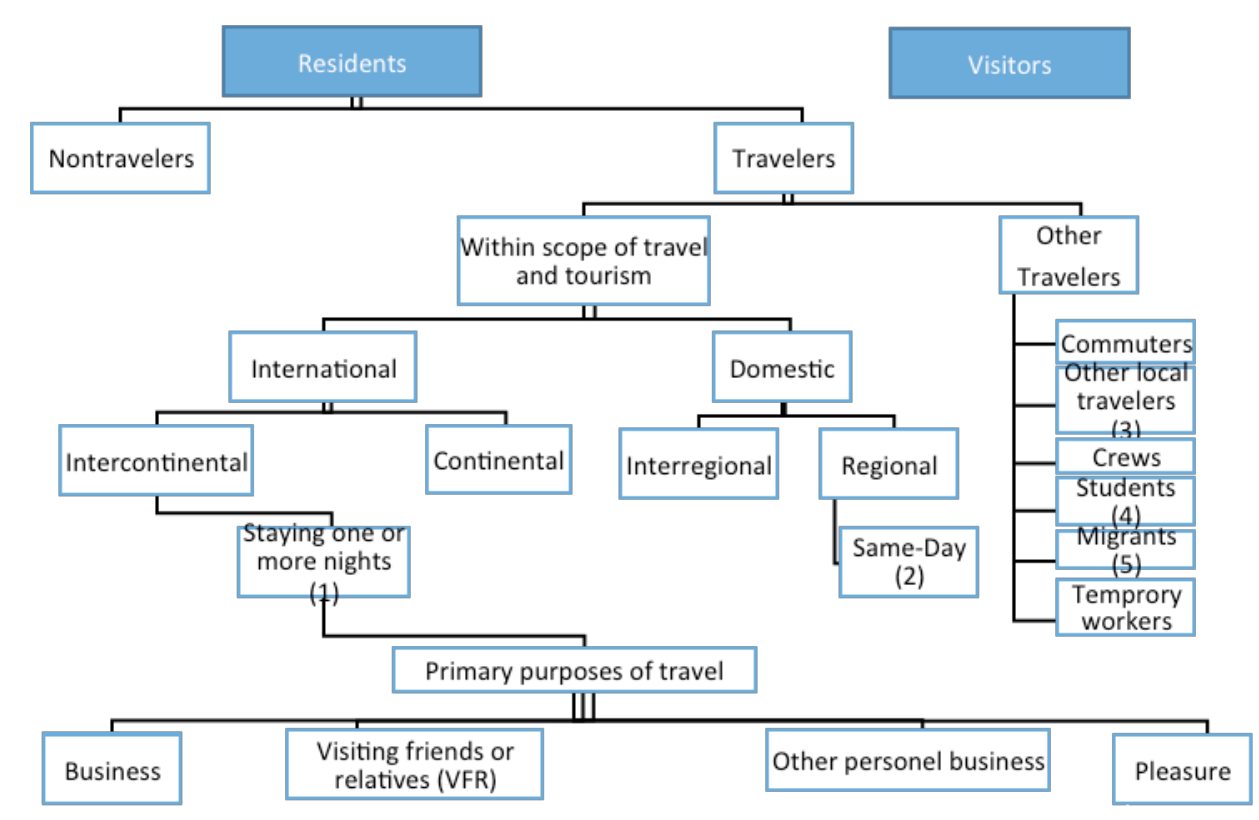

Fig. 3. Classification of Travellers.

Resource: Goeldner and Ritchie, 2009, pp. 11

After these definitions, it will be easier to understand who can be called as tourists. In 1974 Erik Cohen described the six factors that tourists have. These factors are (Cohen, 1974):

- Tourist is a temporary stopover with a permanent residence. Having a fixed address makes the tourist different from the nomads.

- Tourists are those who have their own will and participate voluntarily. He can end his trip at any time and return to his permanent address. This situation is different from tourists, exiles, refugees, prisoners of war, involuntary or forced travelers.

- Tourist performs a round-trip action. The starting point of touring is actually the ultimate destination that he wants to reach. This makes it possible for tourists to differ from travelers on a one-way journey.

- Tourists take a relatively long journey. This situation distinguishes him from day-olds. In the definition of the WTO in 1991, it was stated that a tourist should stay at least one night (WTO, 1995).

- Tourist is the one who prefer different destinations instead of making regular visits. This distinguishes the tourist from the weekend travelers. 
- Tourist is an explorer. Tourists struggle is only on his trip and his trip may not be combined for any other purpose. This factor distinguishes tourists from businesspeople, international representatives, missionaries and those who travel primarily for economic, political or religious purposes.

In Tribe's (2009) study, the condition of being a tourist; summarized in the form of the beginning and ending of the trips and travels made in the same place, and the necessity of starting and ending the journey 'home' in order to be counted as a tourist (Tribe, 2009).

Briefly tourist behavior always takes place in time and space as spatial temporal behavior (Asakura and Hato, 2004; Lau and McKercher, 2006; Shoval and Isaacson, 2007). In this context, relationship time and space as a temporal mobility indicate a person who is a tourist. The first definitions about tourism concept emphasize temporary mobility in the context of place and time relation. Furthermore, tourism has been enriched with time by adding the multidimensional direction to tourism and tourist as a sociological object who is the heart of tourism mobility.

After the concepts of tourism and tourist are looked through as etymological and conceptual framework, euthanasia, another important concept of study, will be correct to discuss in detail. Since 400 B.C. euthanasia, derived from eu (good, beautiful) and Thanatos, is described as the quick and good death of the suffering by Greek and Roman philosophers (Birnbacher, 2015). Euthanasia, known to have emerged in 280 B.C., is used by Steven H. Miles to express "a natural death without pain." In this sense, Miles claims that the historian William Lecky used the term euthanasia in 1869 to give new meaning to today. It is stated that euthanasia before 17th century meant to say goodbye to a peaceful death by living for sobriety and virtue (Gruman, 1978, pp. 261).

First of all, it is essential to distinguish between the concepts of suicide and euthanasia. When suicide is knowingly and willingly ending one's own life; euthanasia can be described as a request for death and an end to life in the face of unbearable sufferings. Beyond the euthanasia, assisted suicide has been termed as dignity death, mercy killing, and patient-oriented death in the literature. These expressions, which are not adopted by doctors, are mostly related to the suicide advocates hiding their advocacy by going to different analogies with the effort to beautify death (Harned, 2012; Theofanidis and Mecek, 2016). For example, when Compassion \& Choices (2016) prefer 'aid in dying' or 'death with dignity', indicating that usage of terms as 'euthanasia' and 'assisted suicide' in the medical literature is incorrect. On the other hand, Dignitas (2014) describe euthanasia as 'provisional green light' with slogan of 'to live for dignity, to die for dignity'. Euthanasia, which means 'good death' in Greek, is used 'physician assisted suicide', 'physician assisted death' and 'euthanasia' in the medical literature and academic studies (Ardelt, 2003, pp. 424). Although euthanasia and assisted suicide are considered different practices in the legal context, they are used instead of each other (Symeonidou-Kastanidou, 2006). Scientifically and generally speaking, euthanasia is defined as ensuring that terminally ill patients with mental proficiency live a peaceful death process in order to put an end to the unbearable pain (Harned, 2012). Euthanasia is killing someone else deliberately, consciously and directly lethal injection, while assisted suicide is supplying of the means (drugs or equipment) that will lead to the deliberate and direct death of someone else, informing the person demanding the death (Symeonidou-Kastanidou, 2006). The "assistance", 
refers to the act of providing patient seeking death with means by doctors and other health-care professionals to end patient's own life (Vilela and Caramelli, 2009). Euthanasia is used as active, passive, voluntary, non- voluntary and involuntary because of differences in practice by doctors (Ardelt, 2003, pp. 424).

\section{Table 2. Types of Euthanasia}

\begin{tabular}{|l|l|}
\hline TYPE & DEFINITION \\
\hline Active Euthanasia & Using a specific method that causes a patient to die. \\
\hline Passive Euthanasia & $\begin{array}{l}\text { Quiting a treatment or rejecting the patient's treatment. That may lead to } \\
\text { the death of a patient. }\end{array}$ \\
\hline Voluntry Euthanasia & Assisting patient in requesting for ending life in a painless manner. \\
\hline Nonvoluntry Euthanasia & $\begin{array}{l}\text { If the patient's consciousness is closed, assisting die by applying to the } \\
\text { patient's legal representatives' will or to the patient's default wish. }\end{array}$ \\
\hline Involuntry Euthanasia & $\begin{array}{l}\text { When a fatal physical or permanent mental condition is concerned, } \\
\text { assisting die by the will of the physician regardless of the will of the } \\
\text { patient. }\end{array}$ \\
\hline
\end{tabular}

Adopted from: Ardelt, 2003; Emanuel, 1994; Emanuel, Onwuteaka-Philipsen, Urwin, and Cohen, 2016; Harned, 2012; Rachels, 1975; Shuriye, 2011; SymeonidouKastanidou, 2006.

Despite the differences in practice of euthanasia types described in Table 2, there are several characteristics in common between euthanasia and assisted suicide such as existing an illness, existing a one-way ticket to something in the direction of existing treatment modalities, a level of pain unbearable to the patient who have mental competence, and clearly demanding the end of his life (Eroğul, 1993; Harned, 2012). After minor differences of euthanasia and assisted suicide are revealed, in accordance with tourism literature we prefer to refer voluntary active euthanasia (VAE), physician assisted suicide (PAS) and assisted suicide (AS) in return for all practices of euthanasia in this paper.

An incurable illness, defined as 'a series of distinct diseases, conditions, or disasters', is used for a number of diseases, including untreatable and unalterable asthma and diabetes. However, some untreatable illness can be controlled or patients can be strengthened. In addition, the patients, demanded to assisted suicide, may be depressed, weak and patients' mental competence may be badly affected during their illnesses (Harned, 2012). By adding to the developments of the medical world progressing every passing day, untreatable illness should be examined in this context. Also, lack of knowledge plays a significant role in the procedure of treatment. Furthermore, the concept of unbearable pain is determined by the subjective judgment of the patient, so the qualification of the doctor will not be objective (Eroğul, 1993). With general expression, pain is complex perception experiences caused by different elements (Chapman, Casey, Dubner, Foley, Gracely and Reading, 1985). And pain is not clearly defined because every human being perceived pain as an internal vision (Beecher, 1957). Pain is a unique perception because the senses emerge from the psychological process and reaction components in vague quantities. It is not a matter of stability since the pain threshold changes from person to person, from time to time. As a result of the studies made in this subject, it is emphasized that the generalizations cannot be reached and pain is temporary. There is no distinction between the experimental pain and the pathological pain caused by tissue and nerve damages (Coderre, Katz, Vaccarino and Melzack, 1993) in the studies conducted due to the subjectivity (Beecher, 1957). On the other hand, Gauthier, Mausbach, Reisch, Bartsch's studies (2015) on 
Switzerland indicate that the main causes of euthanasia are nervous diseases $(47 \%)$, cancer $(37 \%)$, rheumatic diseases and cardiovascular diseases $(28 \%)$.

According to the definition of World Health Organization (WHO), palliative care is an approach aimed at raising the quality of life of patients and their relatives who are fighting life-threatening diseases. This approach includes physical, psychosocial and spiritual care as well as relieve one's pain. The WHO states that palliative care approves life and respects death as a normal process. At the same time, palliative care emphasizes that neither intends to accelerate death nor intends to delay it (WHO, 2016).

Antithetically right to die, the European Union, defending the right to life as 'the transformation into an obligation to live, even in a situation of great suffering', maintains that euthanasia and assisted suicide must be permanently banned (Caldwell, 2012; European Humanist Federation, 2000; European Centre for Law \& Justice (ECLJ), 2012; Puppinck, 2012). The guide on the decision-making process regarding medical treatment in end-of-life situations, was drawn up by the Committee on Bioethics of the Council of Europe, do not include the concepts of euthanasia and assisted suicide. Based on the fundamental rights and freedoms set forth in the European Convention on Human Rights in the framework of the medical decisionmaking process in the last period of life, principles of autonomy, beneficence and nonmaleficence and justice have been set as the internationally accepted principles of medical ethics by the European Convention on Human Rights and Biomedicine (Council of Europe, 2015; WMA, 1981).

Table 3. Perspectives of European Convention on Human Rights and Biomedicine and Declaration on the Rights of Patients

\begin{tabular}{|c|c|}
\hline $\begin{array}{c}\text { The European Convention on Human Rights } \\
\text { and Biomedicine } \\
\text { (Council of Europe, 2015). }\end{array}$ & $\begin{array}{c}\text { Declaration on the Rights of Patients } \\
\text { (World Medical Association (WMA), 1981) }\end{array}$ \\
\hline $\begin{array}{c}\text { Principle of Autonomy } \\
\text { 'allowing any medical practice or attempt after } \\
\text { the person making choices about himself, } \\
\text { deciding without any pressure and influence and } \\
\text { after informed in an understandable manner } \\
\text { about his situation' }\end{array}$ & $\begin{array}{c}\text { Article } 3 \text { states that a mature patient with mental } \\
\text { competence should approve or reject an initiative } \\
\text { for any diagnosis or treatment. In the case of the } \\
\text { patient who died as the result of rejecting the } \\
\text { treatment, the condition is evaluated as passive } \\
\text { euthanasia. }\end{array}$ \\
\hline $\begin{array}{c}\text { Principle of Beneficence And Non-Malefcence } \\
\text { 'a dual obligation that the physician considers } \\
\text { the benefit-harm balance of the patient to serve } \\
\text { the highest possible benefit by minimizing } \\
\text { possible risks and harms as far as possible. } \\
\text { Possible risk and harm may not only be physical, } \\
\text { but may also be a situation about psychological } \\
\text { or violation of right to privacy and the individual } \\
\text { privacy' }\end{array}$ & $\begin{array}{c}\text { Article } 1 \text { is intended that the patient be treated in } \\
\text { such a way that the highest benefit is always } \\
\text { preserved. }\end{array}$ \\
\hline $\begin{array}{c}\text { Principle of Justice } \\
\text { 'Justice means that every person receives } \\
\text { medical care without any discrimination, and } \\
\text { that the available resources are distributed } \\
\text { potentially in the fairest possible manner'. }\end{array}$ & $\begin{array}{l}\text { This principle is guaranteed by the Declaration of } \\
\text { Patients' Rights and emphasizes the importance of } \\
\text { a fair approach to illness. }\end{array}$ \\
\hline
\end{tabular}

Adopted from: Council of Europe, 2015, WMA, 1981.

Euthanasia has been discussed in a very long time in medical literature since the first written source of doctors' duties, gets Hippokrat's name (known as the father of 
medicine). In particular, it is emphasized that the physician should not give the patient a lethal drug (active euthanasia) or recommend it, even if the patient wishes (Markel, 2004). It is also stated that in the framework of the International Medical Ethics, which was published in 1949 and updated in 1968, 1983 and 2006 by the World Medical Association, the importance of respect for human life has always been emphasized and the right of the patient to accept and reject treatment (WMA, 2006).

WMA announced with Declaration on Euthanasia in 1987, 2005 and 2015 that euthanasia was not ethical, by emphasizing that the wishes of a patient in the late stages of his medical illness should be respected. The Euthanasia Declaration shows that "euthanasia, the act of deliberately ending a patient's life, is not ethical even if it is done at the request of the patient himself or close relatives by the way thinking of respecting patient's willingness to allow the natural death process." (WMA, 1987). Statement On Physician-Assisted Suicide in 1992, 2005 and 2015 shows that deliberately and willingly ending an individual's life is not an ethical practice, such as euthanasia and physician assisted suicide (WMA, 1992). In order to emphasize the importance of providing quality palliative care in the last period of life, WMA provide guidance for assisting patients with Declaration of Venice on Terminal Illness in 2006 and Declaration on End of Life Medical Care in 2011 (Williams, 2015, pp. 60).

Euthanasia has been tried to be included in the literature of tourism as "euthanasia/assisted suicide tourism" and "euthanasia/assisted suicide tourist" by various authors. Euthanasia / assisted suicide tourism in these studies is defined as "the desire to die for a person with various health problems and to travel elsewhere, because he cannot fulfill this desire because of the legal obstacles at his place of residence". Those who carried out this action were also described as "euthanasia/assisted suicide tourist" (Huxtable, 2009; Miller \& Gonzales, 2013; Safyan, 2011).

\section{COUNTRIES' LAW AND MEDICAL PERSPECTIVE OF EUTHANASIA}

Efforts to change government policies on euthanasia in the 20th and 21 st centuries have achieved limited success in the western countries. The euthanasia policies of countries have been developed by various non-governmental organizations, especially medical associations and defense organizations. Euthanasia and assisted suicide is legal in the Netherlands, Belgium, Colombia and Luxembourg, Canada and USA's states of California, Montana, Oregon, Vermont and Washington DC. Besides these countries, Switzerland is the only country which practices euthanasia and assisted suicide but has no legal regulations. All countries that accept euthanasia and assisted suicide require that the patient be in unbearable harshness, have an untreatable illness, and have doctor's approval in order to be able to perform this procedure. (Jonquiere, 2016; Private interview 05.12.2016; ProCon, 2017; The Richest, 2017). Besides the countries that accepted VAE, PAS and AS these are seen as crime in many countries around the world.

The World Health Organization and the World Union of Nations emphasize euthanasia and assisted suicide as an ethical practice. However, the countries that advocate euthanasia are members of both (see the table 4). In addition, despite the concept of euthanasia and assisted suicide, which does not fit the UNWTO definition of tourism, which is globally accepted, countries outside Belgium, Luxembourg and Canada are also members of UNWTO. For this reason, the so-called countries, which 
advocate an application contrary to the approaches of the global organizations to which they belong, constitute a contradiction.

Table 4. Countries with euthanasia and assisted suicide praxis and organization memberships

\begin{tabular}{|c|c|c|c|c|c|c|c|}
\hline$\underset{\Xi}{\stackrel{\Xi}{\Xi}}$ & 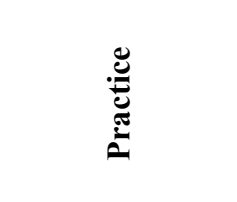 & & $\underset{\pi}{2}$ & 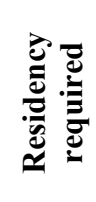 & 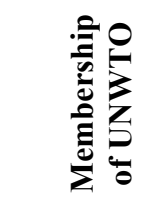 & 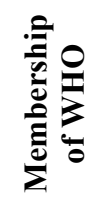 & 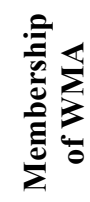 \\
\hline Netherlands & $\begin{array}{c}\text { Euthanasia- } \\
\text { Assisted suicide }\end{array}$ & 2002 & $12+$ & Yes & $\begin{array}{c}\text { Yes } \\
\text { Since } 1976\end{array}$ & Yes & Yes \\
\hline Belgium & $\begin{array}{c}\text { Euthanasia- } \\
\text { Assisted suicide }\end{array}$ & 2002 & $\begin{array}{l}\text { Any } \\
\text { age }\end{array}$ & Yes & No & Yes & Yes \\
\hline Luxembourg & $\begin{array}{c}\text { Euthanasia- } \\
\text { Assisted suicide }\end{array}$ & 2009 & $18+$ & Yes & No & Yes & Yes \\
\hline Switzerland & Assisted suicide & 2 & $18+$ & No & $\begin{array}{c}\text { Yes } \\
\text { Since } 1976\end{array}$ & Yes & - \\
\hline USA & Assisted suicide & 3 & $18+$ & Yes & No & Yes & Yes \\
\hline Canada & $\begin{array}{c}\text { Euthanasia- } \\
\text { Assisted suicide }\end{array}$ & 2016 & $18+$ & Yes & No & Yes & Yes \\
\hline Japan & - & 4 & - & - & $\begin{array}{c}\text { Yes } \\
\text { Since } 1978\end{array}$ & Yes & Yes \\
\hline Colombia & $\begin{array}{c}\text { Euthanasia- } \\
\text { Assisted suicide }\end{array}$ & 2015 & $18+$ & Yes & $\begin{array}{c}\text { Yes } \\
\text { Since } 1975 \\
\end{array}$ & Yes & Yes \\
\hline
\end{tabular}

Elaborated by author(s): Adams and Nys, 2003; Anonymous, 1988; Appel, 2004; BBC, 2015a; BBC, 2015b; BBC,2016; Belgian Ministry of Justice, 2002; Burleigh and Boyd, 1995; Care, 2016; Castan Centre for Human Rights Law, 2015; Emanuel, 1994; End of Life Law in Canada, 2016; Globalnews, 2016; Griffiths, Weyers and Adams, 2008; Health Law Institute, 2016; Huffingtonpost, 2016; Hurst and Mauron, 2003; Hurst and Mauron, 2016; Inceoğlu, 1998; Jans, 2005; Julezs, 2016; Kroneman, Boerma, Berg, Groenewegen, Jong, Ginneken, 2016; Legilux, 2009; Luxembourgpublic, 2016; Manav, 2016; Materstvedt, et al. 2003; National Academy of Science and Engineering and Union of the German Academies of Sciences and Humanities, 2015; Pereira, 2011; ProCon, 2017; Rob Jonquiere, private interview 05.12.2016; Sayid, 1983; Scherer and Simon, 1999; Smets, Bilsen, Cohen, Rurup and Deliens 2010; Stajano, 2015; Varadarajan, Freeman and Parmar, 2016; World, 2015.

\section{WHAT RELIGIONS SAY?}

In this part, euthanasia and life issues is evaluated in terms of religions. As the subject, five religions, including Hinduism, Buddhism, Judaism, Christianity and Islam, with the most believers in the world, were studied. The religions and the approaches of the subjects covered in the study were presented in accordance with religious chronology.

Death is an important step in the Samsara cycle for Hindus who want to reach Nirvana, and are classified into three types: naturally occurring deaths, death in the accident and war and suicide (Coward, Lipner and Young, 1989, pp. 74). Suicides due

\footnotetext{
${ }^{2}$ Euthanasia is not legal in Switzerland, but assisted suicide can be practiced because the grey areas in the law.

35 states (California, Colorado, Oregon, Vermont, and Washington DC) legalized physician-assisted suicide via legislation. 1 state (Montana) has legal physician-assisted suicide via court ruling.

${ }^{4}$ The Japanese government has not made any legal arrangements for euthanasia. It is possible to say that, although there are no regulations in the legal sense, the euthanasia view of Japanese law is shaped by the decision of two local courts. While these were the 1962 decision of the Nagoya court on passive euthanasia, the second is the 1995 date given to the active euthanasia in the wake of the incident that took place at Tokai University. With these two court decisions, the legal framework for euthanasia has been envisaged and it has been stated that both active and passive euthanasia can be legally observed under certain conditions (Scherer and Simon, 1999).
} 
to the stress, depression and suffering experienced, which are considered to be only a type of suicide, are not accepted by Hindus. These voluntary suicides are strictly forbidden in the Holy Scriptures accepted by Hindus and strongly opposed in Smriti, Dharmasastra, Parasara and Mahabharata. It is told in Parasara that the people who commit suicide will be formed again in the form of a bad entity in the world after suffering for six thousand years during soul emigration (Coward et al, 1989, pp. 92). According to the Hindu karma theory, the soul and the body should be separated from each other at the right time, so doctors are disapproved to apply euthanasia to his patients. If this is allowed, it is thought that both the doctors and the patients' complication will suffer from this situation (Nimbalkar, 57).

Buddhism also has a mixed and tenacious belief, one of the common features of Indian religions. According to the karma belief in Buddhism, good or bad experiences in the lives of the living beings will be influenced by their previous lives and will affect the following. The first of five basic teachings of Buddhism is "to avoid taking a life". According to Buddhist belief, suicide is within the scope of akusala acts which cause rebirth to be in bad conditions (Güngör, 2004, pp. 245). Buddhism describes suicide as a way to keep the path of life short on the path of death. This notion means missing the new life story in the cycle, reducing the preparation time to death, interrupting life and end it suddenly (Leong and Leach, 2008: 123; Ratanakul, 2009) and so it is not accepted (Delhey, 2006, pp. 54; Tsomo, 2006, pp. 174; Analayo, 2014, pp. 25) even seen as a crime (Keown, 2005, pp. 953).

The Ten Commandments reminds the Jewish people some of their moral and sacred duties. One of the ten commandments is "Thou shalt not kill" (Exodus 20:13) and this order shows that God takes note of people's lives. The important thing here is that this order not valid in battlefields. This order also has a sense that respecting person's live and express that human life is precious under all circumstances. Considering the scope of this study, this commitment forbids somebody to take somebody else's life whether it be by their own consent or because of the deadly disease they suffer from. Moses tells Jews that they prefer to keep body and soul together by mentioning the importance of life, and thus, this preference will be reflected on their children, and said that clinging to the life was the same with hooking themselves on their Lord (Bible-Deuteronomy 30: 19-20; Bible-Leviathans 18:1-5; Bible-Genesis 9: $5)$.

According to the Christianity, the life is given by the God. In Luka, it is said about this situation: "Neither is worshipped with men's hands, as though he needed anything, seeing he giveth to all life, and breath, and all things" (Bible-Luka 17: 25). According to this holy writing, God has given right to both life and breathing to humankind and the life is sacred because it comes from the God. In respect to Christianity, there is no difference between suicide and Euthanasia. Accordingly, someone's suffering is to be close to Jesus and be part of his aches and pains. For doing this, there is need to make self-sacrifice (Bible-Acts of Apostles 17:25; 1; Bible-Corinthians 3: 16-17, 15: 26). Some patients should acknowledge their pain voluntarily. Sick people should not escape from the death, contrarily, should face death sedately. The Catholic Church, has a view that does not give approval Euthanasia, due to the life is presented to mankind by the God. This is because, abridgment of the life of patient's mean for in a special facility. Therefore, it is illegal to initiate the procedure unless the person has made the current preparation for death (New Advent, 2017). The opinion of the Orthodox Church about 
Euthanasia shows parallelism with the Catholic Church. In reference to this church, to suicide and to help someone to depart this life is not honorable behavior (Sümer, 2015, pp. 122,123). Protestant Church has corroborated that what was created in the image of God and intentionally destroyed is contrary to the Christian conscience, also has expressed its opposition to the enactment of doctor-assisted death, which would allow someone to be specifically killed (End of Life Decisions, 1992, pp. 4).

According to Islam, the most important blessing that man does not appreciate is life. Life is Allah's incarnation to human and no one can have it against the will of Allah (15 / Quran-Hijr, 23; 50 / Quran-Qayf, 43; Paşa, 1955, pp. 90). For this reason, killing a person and attacking his/her life unfairly is forbidden (Kaya, 1994, pp. 134). The prominence of human life is given in the Qur'an by considering killing a person equal with killing all humanity (Quran-Mâide 32). Islam also protects one's own right to live; According to Islamic belief, one does not have the luxury of saying 'this life is mine, I will destroy myself if I wish' (Dölek, 2009, pp. 20; Duman, 2008, pp. 35; Yiğit, 2000, pp. 340). In the belief of Islam, it is considered as sin that a man ends his life with his hands (Doğan, 1968). Islamic belief is based on trusting in Allah in bad situations, coping and surrendering; in other words, it is based on faith (A $\mathrm{g}_{1} 1 \mathrm{kaya}, 2010$, pp. 174; Kaşıkç1, 2008, pp. 91). It is commanded to trust in Allah (Quran-Enfâl, 8/2-3; QuranHûd, 11/56; Quran-Mâide, 5/11; Quran-Talak, 65/3; Quran-Tevbe, 9/51; Quran-Tevbe, 9/129).

\section{CONCLUSION}

The concepts of VAE, PAS and AS are very often encountered concepts, but differ from country to country in terms of implementation. Euthanasia, which is a subject of much debate in terms of philosophical, religious and ethical aspects, is not accepted as a legal practice in many countries around the world (Gielen, Van den Branden and Broeckaert, 2009; Seale, 2009). While some countries (numerus clausus) legally allow euthanasia and assisted suicide, in some countries, laws do not provide a complete framework for these cases. In countries where religious laws are heavily repressed, practices are being based on the views of religious authorities. In other countries; medical and legal rules are based on. VAE, PAS and AS, discussed in legal, medical and religious terms, has begun to be implemented without any clear framework and tourism has become a subject. Within the scope of this study, it was discussed that legal, medical and religious debates about whether VAE, PAS and AS could be considered as a tourism variety or not. While legal and medical arrangements are parallel to each other, some countries such as the Netherlands and Belgium, as seen in the study, set the laws and rules on euthanasia and assisted suicide in a complete framework, while some countries, like Switzerland, are on their way to stretching their laws based on medical rules in the direction of their economic interests. In countries like Japan, where there is no relevant legal or medical regulation, applications are made according to the outcome of the lawsuits related to this issue.

Considering the etymology and definitions of tourism/tourist and visitor; made by various researchers and world-wide organizations, whether the definition's scope, geography, sociology, psychology or economics, it has always been emphasized that tourism activity must be in out of the traveler's usual environment, not more than one consecutive year for leisure, business and other purposes and consist a "return" (Beaver, 2002; Bell and Ward 2000; Cohen, 1974; Cooper, 2013; Cooper and Hall, 2008; 
Gilbert, 1990; Gilbert, 2004; Goeldner and Ritchie, 2009; Govers, Van Hecke and Cabus, 2008; Hall, Williams and Lew, 2004; Holloway, 1989; Hunt and Layne, 1991; Hunziker \& Krapf, 1942; Jayapalan, 2001; Leiper, 1979; Leiper, 1990; Medlik, 2003; O'Reilly, 2003; Sicart, 2016; Schullern zu Schrattenhofen 1911; Urry, 1992, Urry and Larsen, 2001; Theobald, 2005; Williams and Hall 2000; UNWTO, 1990-1995-2016). It is a truth that VAE, PAS and AS practices contain a mobility, but that does not mean that it can be situated as a type of tourism, because this mobility requires just "one-way ticket". Instead of naming this mobility as "tourism", it may be named as "medical immigration or euthanasia/assisted suicide mobility". In the light of all these definitions and explanations about tourism, tourist, visitor, euthanasia, assisted suicide it can be said, it is not right to name this kind of organizations as tourism businesses.

For the future studies; all studies that have been made about VAE, PAS and AS mobility is focused on international mobility. But most countries that practices VAE, PAS and AS is allowed to domestic praxis. That shows how the literalize of VAE, PAS and AS mobility practices are wrong. 


\section{REFERENCES}

Ağılkaya, Z. (2010). İntihar ve Din: İntihar Girişiminde Bulunanlar Üzerine Empirik Bir Araştırma. MÜIF Dergisi. 38 (1). 173-202.

Adams, M., and Nys, H. (2003). Comparative Reflections on the Belgian Euthanasia Act 2002. Medical Law Review. 11(3). 353-376.

Anālayo, B. (2014). Karma and Female Birth. Journal of Buddhist Ethics. 21. 109-159.

Anonymous. (1988). It's over, Debbie. JAMA Medical Association. 259:269

Appel, J., M. (2004). A Duty to Kill? A Duty to Die? Rethinking The Euthanasia Controversy of 1906. Bulletin of the History of Medicine. 78 (3). 610-634.

Ardelt, M. (2003). Physician-Assisted Death. (Edited by Clifton D. Bryant). Handbook of Death and Dying. Thousand Oaks. Sage. CA.

Asakura, Y. and Hato, E. (2004). Tracking Survey for Individual Travel Behaviour Using Mobile Communication Instruments. Transportation Research Part C: Emerging Technologies. 12(3), 273-291.

BBC. (2015a). [http://www.bbc.com/news/world-34445715] 06.10.2015. (Date of access: 28.11.2016).

BBC. (2015b). [http://www.bbc.com/news/world-latin-america-33392195] 03.07.2015. (Date of access: 28.11.2016).

BBC. (2016). [http://www.bbc.com/news/world-us-canada-36566214] 18.06.2016. (Date of access: 28.11.2016).

Beaver, A. (2002). A Dictionary of Travel and Tourism Terminology. CAB International, Wallingford.

Beecher, H., K. (1957). The Measurement of Pain Prototype for the Quantitive Study of Sunjective Responses. Pharmacological Reviews. 9(1). 59-209.

Belgian Ministry of Justice. (2002). [http://www.ethicalperspectives.be/viewpic.php?TABLE=EP\&ID=59] (Date of access: 28.11.2016).

Bell, M. and Ward, G. (2000). Comparing Temporary Mobility with Permanent Migration. Tourism Geographies. 2(1). 87-107.

Bible-Acts of Apostles (2017). https://www.biblegateway.com/passage/?search=Acts+ 17\%3A25 (Date of access: 12.06.2017).

Bible-Corinthians (2017). https://www.biblegateway.com/passage/?search=1+ Corinthians $+3 \% 3 \mathrm{~A} 16-17 \&$ version=ESV (Date of access: 13.06.2017).

Bible-Deuteronomy (2017). https://www.biblegateway.com/passage/?search= Deuteronomy+30\%3A19-20 (Date of access: 12.06.2017).

Bible-Genesis (2017). http://biblehub.com/genesis/9-5.htm (Date of access: 12.06.2017).

Bible-Leviathans (2017). https://www.biblegateway.com/passage/?search=Lev\%2018: 1-Lev\%2018:5 (Date of access: 12.06.2017).

Bible-Luka (2017). https://www.biblegateway.com/passage/?search=Luka+17\%3A25\& version=SNT (Date of access: 12.06.2017).

Birnbacher, D. (2015). Euthanasia, (Edited by James D. Wright), International Encyclopedia of the Social \& Behavioral Sciences (Second Edition). Elsevier. London. 
Burleigh, M. and Boyd, C., E. (1995). Death and Deliverance: "Euthanasia" in Germany, 1900-1945. History: Reviews of New Books. 24(1). 36-36.

Caldwell, S. (2012). Euthanasia 'Must Always Be Prohibited', Rules Council of Europe. Mailonline. Retrieved from [http://www.dailymail.co.uk/news/article2092872/Euthanasia-prohibited-rules-Council-Europe.html]. (Date of access: 28.06.2017).

CARE. (2016). Country Comparison. [http://www.care.org.uk/our-causes/sanctitylife/assisted-suicide-euthanasia/country-comparison] (Date of access:18.04.2016).

Castan Centre for Human Rights Law, Euthanasia Laws (2015) Have you got that right? [http://www.haveyougotthatright.com/s-ep3-laws] (Date of access:10.04.2016).

Chapman, C., R., Casey, K., L., Dubner, R., Foley, K., M., Gracely, R., H. and Reading, A., E. (1985). Pain Measurement: An Overview. Pain. 22(1). 1-31.

Coderre, T., J., Katz, J., Vaccarino, A., L. and Melzack, R. (1993). Contribution of Central Neuroplasticity to Pathological Pain: Review of Clinical and Experimental Evidence. Pain. 52. 259-285.

Cohen, E. (1974). Who Is a Tourist? A Conceptual Clarification. The Sociological Review. 22(4). 527-555.

Cohen, E. (1984). The Sociology of Tourism: Approaches, Issues, and Findings. Annual Review of Sociology. 10(1). 373-392.

Compassion \& Choices. (2016). Aid in Dying: History \& Background for Students, Activists and Professionals. [https://www.compassionandchoices.org/wp content/uploads/2016/02/Aid-in-Dying-History-and-Background.pdf] (Date of access: 28.04.2017).

Cooper, C. (2013). Essentials of Tourism. Prentice Hall. Harlow, United Kingdom.

Cooper, C. and Hall, C., M. (2008). Contemporary Tourism: An International Approach. Butterworth-Heinemann. Oxford.

Council of Europe. (2015). Guide Sur Le Processus Décisionnel Relatif Aux Traitements Médicaux Dans Les Situations De Fin De Vie,/Yaşamin Son Döneminde Tıbbi Tedavide Karar Verme Sürecine Ilişkin Kılavuz. (Translated by Yeşim Iş1 Ülman).

Coward, H., G., Lipner, J., J., Young, K., K. (1989). Hindu Ethics, Purity, Abortion and Euthanasia, State University of New York Press. New York.

Crompton, J., L. (1979). Motivations for Pleasure Vacation. Annals of Tourism Research. 6(4). 408-424.

Dann, G., M. (1977). Anomie, Ego-enhancement and Tourism. Annals of Tourism Research. 4(4). 184-194.

De Esteban, J., Cetin, G. and Antonovica, A. (2015). Theory of Knowledge of Tourism: A Sociological and Epistemological Reflection. Journal of Tourismology.1(1).2-15.

Delhey, M. (2006). Views on Suicide in Buddhism: Some Remarks. (Edited by M. Zimmerman). Buddhism and Violence. LIRI Seminar Proceeding Series Lumbini International Research Institute Volume 2. Nepal.

Demen Meier, C. (2005). Le Tourisme : Essai De Définition. Enseignante Marketing. Ecole Hôtelière de Lausanne. Université de Caen. France.

Dignitas. (2014). How DIGNITAS Works. Forch. Switzerland. 
Dignitas. (2016). To Live with Dignity - To Die with Dignity. 13th Edition. Retrieved from [http://www.dignitas.ch/images/stories/pdf/informations-broschueredignitas-e.pdf] (Date of access: 22.04.2017).

Doğan, L. (1968). İslamda Yaşama Hakkı. DiBB Dergisi. 7. 60.

Dölek, A. (2009). İnsanın Yaşama Hakkının Korunmasının Dini Dayanağı, Çanakkale On Sekiz Mart Ünversitesi Yayınları. Sempozyum Bildirileri. 18-39.

Duman, Z. (2008). Dinî Açıdan Problem Oluşturan Tıbbî Meseleler. Güncel Dini Meseleler İstişare Toplantısı-II. Diyanet İşleri Başkanlığı Din İşleri Yüksek Kurulu Başkanlığı. Ankara.

Emanuel, E., J. (1994). The History of Euthanasia Debates in the United States and Britain. Annals of Internal Medicine. 121(10), 793-802.

Emanuel, E., J., Onwuteaka-Philipsen, B., D., Urwin, J., W. and Cohen, J. (2016). Attitudes and Practices of Euthanasia and Physician-Assisted Suicide in the United States, Canada, and Europe, JAMA. 316(1):79-90.

End of Life Decision. (1992). Evangelical Lutheran Church in America. [http://download.elca.org/ELCA\%20Resource\%20Repository/End_Life_Decisio nsSM.pdf] 8Date of access: 11.12.2016).

End of Life Law in Canada. (2016). [http://eol.law.dal.ca/?page_id=236] (Date of access: 05.12.2016)

Eroğul, C. (1993). Ölüm Hakkı. Ankara Üniversitesi Siyasal Bilgiler Fakültesi Dergisi. 48(1-4). 47-56.

European Centre For Law \& Justice (ECLJ). ( 2012). ECLJ: Major Victory For Life In Europe: "Euthanasia Must Always Be Prohibited". Retrieved from [https://eclj.org/eclj-major-victory-for-life-in-europe-euthanasia-must-always-beprohibited]. (Date of access: 23.05.2017).

European Humanist Federation. (2000). Euthanasia and the Parliamentary Assembly of the Council of Europe. [http://humanistfederation.eu/ckfinder/userfiles/files/ position/star-and-end-of-life/Statement-on-the-PACE-Debate.pdf] (Date of access: 23.05.2017).

Gauthier, S., Mausbach, J., Reisch, T. and Bartsch, C. (2014). Suicide Tourism: A Pilot Study On the Swiss Phenomenon. Journal of Medical Ethics. (41). 611-617.

Gilbert, D., C. (1990). The Nature and Structure of Tourism. (Edited by S. Williams). Tourism, Critical Concepts in the Social Sciences. Taylor \& Francis.

Gilbert, D., \& Abdullah, J. (2004). Holidaytaking and the sense of well-being. Annals of Tourism Research, 31(1), 103-121.

Globalnews. (2016). [http://globalnews.ca/news/2638235/assisted-dying-in-canadawhat-you-need-to-know-about-the-new-law/] (Date of access: 05.12.2016).

Goeldner, C., R. and Ritchie, J., R., B. (2009). Tourism: Principle, Practices, Philosophies. 11th Edition. John Wiley \& Sons. New Jersey.

Govers, R., Van Hecke, E. and Cabus, P. (2008). Delineating Tourism: Defining the Usual Environment. Annals of Tourism Research. 35(4), 1053-1073.

Griffiths, J., Weyers, H. and Adams, M. (2008). Euthanasia and Law in Europe. Oxford and Portland: Hart.

Gruman, G., J. (1978). Death and Dying: Euthanasia and Sustaining Life: I. Historical Perspective, (Edited by Warren T. Reich). Encyclopaedia of Bioethics. London. 
Güngör, A., İ. (2004). Tanrı'nın Şövalyeleri Cizvitler. 2. Baskı. Çağlar Yayınları. Ankara.

Hall, C. M., Williams, A., M. and Lew, A., A. (2004). Tourism: Conceptualizations, Institutions, and Issues (Edited by Alan A. Lew, C. Michael Hall and Allan M. Williams). A Companion to Tourism Blackwell Publishing. UK.

Hall, C., M. (2005). Tourism: Rethinking the Social Science of Mobility. Prentice-Hall. Harlow.

Hall, C., M. and Müller, D. (2004). Tourism, Mobility and Second Homes: Between Elite Landscape and Common Ground. (Edited by C. Michael Hall, Dieter K. Müller). Channelview Publications. Clevedon.

Harned, M., E. (2012). The Dangers of Assisted Suicide No Longer Theoretical, Defending Life 2012. End of Life Issues. Americans United for Life. Retrieved from [http://www.aul.org/wp-content/uploads/2012/04/dangers-assistedsuicide.pdf] (Date of access: 17.05.2017).

Health Law Institute. (2016). End-of-Life Law and Policy in Canada. [http://eol.law.dal.ca/?page_id=236] and [http://eol.law.dal.ca/?page_id=238] (Date of access: 23.05.2017).

Higginbotham, G. (2011). Assisted-suicide Tourism: Is It Tourism? Tourismos: An International Multidisciplinary Journal of Tourism. 6(2). 177-185.

Holloway, J., C. (1989). The Business of Tourism, Third Edition. Pitman Publishing. London.

Huffingtonpost (2016). [http://www.huffingtonpost.ca/news/euthanasia-laws-canada/] (Date of access: 05.12.2016)

Hunt, J., D. and Layne, D. (1991). Evolution of Travel and Tourism Terminology and Definitions. Journal of Travel Research. 29(4). 7-11.

Hunziker, W. and Krapf, K. (1942). Allgejameine Fremdenverkehrslehre. Zurique.

Hurst, S. A., and Mauron, A. (2003). Assisted Suicide and Euthanasia in Switzerland: Allowing A Role for Non-physicians. The British Medical Journal. 326(7383), 271-273.

Hurst, S., A. and Mauron, A. (2017). Assisted Suicide in Switzerland: Clarifying Liberties and Claims, Bioethics. 31(3). 199-208.

Huxtable, R. (2009). The Suicide Tourist Trap: Compromise Across Boundaries. Journal of Bioethical Inquiry. 6(3). 327-336.

Inceoğlu, S. (1998). Hollanda Hukuku'nda Ötanazinin Hukukiliği. Ístanbul Barosu Dergisi. 72(1-2-3). .27-33.

Jang, S. and Cai, L., A. (2002). Travel Motivations and Destination Choice: A Study of British Outbound Market. Journal of Travel \& Tourism Marketing. 13(3). 111133.

Jans, J. (2005). The Belgian" Act on Euthanasia": Clarifying Context, Legislation, and Practice from an Ethical Point of View. Journal of the Society of Christian Ethics. 25(2). 163-177.

Jayapalan, N. (2001). Introduction to Tourism. Atlantic Publishers \& Distributors. New Delhi.

Jonquiere, R. (2016). Interview with Director of the World Federation of Right to Die Societies Communications. 05.12.2016 (robjonquiere@worldrtd.net). 
Julesz, M. (2016). Active Euthanasia in Colombia and Assisted Suicide in California. Orvosi Hetilap. 157(5), 174-179.

Kaşıç̧ı, O. (2008). Hukuk Tarihinde Ötanazi. Türk Hukuk Tarihi Araştırmaları. 6. 8599.

Kaya, A. (1994). İslam Hukukuna Göre Ötenazi. Uludă̆ Üniversitesi İlahiyat Fakültesi Dergisi. 6(6). 133-146.

Keown, D. (2005). End of Life: The Buddhist View. The Lancet. 366(9489). 952-955.

Kroneman M., Boerma W., van den Berg M., Groenewegen P., de Jong J. and van Ginneken E. (2016). The Netherlands: Health System Review. Health Systems in Transition, 18(2). 1-239.

Lau, G. and McKercher, B. (2006). Understanding Tourist Movement Patterns in A Destination: A GIS Approach. Tourism and Hospitality Research. 7(1). 39-49.

Legilux, (2009). Journal Officiel du Grand-Duché de Luxembourg.

Leiper, N. (1979). The Framework of Tourism: Towards a Definition of Tourism, Tourist, and the Tourist Industry, Annals of Tourism Research, 1979, VI(4):390407.

Leiper, N. (1990). Tourist Attraction Systems. Annals of Tourism Research. 17(3). 367384.

Leong, F. and Leach, M. M. (2008). Suicide Among Racial and Ethnic Minority Groups: Theory, Research and Practice. Routledge Press. New York.

Libera, K. (1963). Historical Development of the Role of Tourism, IUOTO. Tourist Correspondence Courses. Genova.

Luxembourgpublic. (2016). [http://www.luxembourg.public.lu/en/vivre/famille/finvie/euthanasie-soinspalliatifs/index.html] (Date of access: 20.12.2016).

Manav, S., C. (2016). Ötanazi ve Yaşama Hakkı. Beykent Üniversitesi Sosyal Bilimler Enstitüsü Hukuk Anabilim Dalı Kamu Hukuku Bilim Dalı Yükseklisans Tezi. İstanbul.

Markel, H. (2004). I Swear by Apollo-on Taking the Hippocratic Oath. $N$ Engl $J$ Med. 350(20). 2026-2029.

Materstvedt, L., J., Clark, D., Ellershaw, J., Førde, R., Gravgaard, A., M., B., MüllerBusch, H., C., ... and Rapin, C., H. (2003). Euthanasia and Physician-assisted Suicide: A View from an EAPC Ethics Task Force. Palliative Medicine. 17(2). 97.

Medlik, S. (2003). Dictionary of Travel, Tourism and Hospitality ButterworthHeinemann. Oxford.

Miller, D., S. and Gonzalez, C. (2013). When Death is The Destination: The Business of Death Tourism-Despite Legal and Social Implications. International Journal of Culture, Tourism and Hospitality Research. 7(3). 293-306.

National Academy of Science and Engineering and Union of the German Academies of Sciences and Humanities (2015). Public Health in Germany - Structures, Developments and Global Challenges. Halle (Saale).

New Advent. (2017). Catholic Encyclopedia, Euthanasia. [http://www.newadvent.org/ cathen/05630a.htm] (Date of access: 06.03.2017).

Nimbalkar, N. (2007). Euthanasia: The Hindu Perspective. National Seminar on Bio Ethics. Joshi- Bedekar College. Thane. 
O'Reilly, K. (2003). When is A Tourist? The Articulation of Tourism and Migration in Spain's Costa del Sol, Tourist Studies. 3(3). 301-317.

Ogden, R., D., Hamilton, W., K. and Whitcher, C. (2010). Assisted Suicide by Oxygen Deprivation with Helium at A Swiss Right-To-Die Organisation. Journal of Medical Ethics. 36(3). 174-179.

Ogilvie, F., W. (1933). The Tourist Movement, Journal of the Royal Statistical Society. 96(4) I .686-688.

Paşa, S. (1955). İslam Hukuk Nazariyâtı Hakkında Bir Etüd (I-II). (Çeviren B. Arıkan). Yeni Matbaa. Ankara.

Pearce, P., L. and Caltabiano, M., L. (1983). Inferring Travel Motivation from Travelers' Experiences. Journal of Travel Research. 22(2). 16-20.

Pereira, J. (2011). Legalizing Euthanasia or Assisted Suicide: The Illusion of Safeguards and Controls. Current Oncology. 18(2). 38-45.

ProCon (2017). Retrieved from [http:// euthanasia. procon.org/ view.resource. php? resourceID=000132] (Date of access: 21.02.2017)

Puppinck, G. (2012). Victory: Council of Europe Adopts Resolution Against Euthanasia. [http://www.lifenews.com/2012/01/26/victory-council-of-europeadopts-resolution-against-euthanasia/] (Date of access: 21.02.2017)

Quran-Enfal (2017) http://www.kuranmeali.org/8/enfal_suresi/2.ayet/kurani_kerim_ mealleri.aspx (Date of access: 13.06.2017).

Quran-Hijr (2017) http://www.kuranmeali.org/15/hicr_suresi/50.ayet/kurani_kerim_ mealleri.aspx (Date of access: 12.06.2017).

Quran-Hûd (2017) http://www.kuranmeali.org/11/hud_suresi/56.ayet/kurani_kerim_ mealleri.aspx (Date of access: 13.06.2017).

Quran-Mâide (2017) http://www.kuranmeali.org/5/maide_suresi/32.ayet/kurani_kerim_ mealleri.aspx (Date of access: 14.06.2017).

Quran-Qayf (2017) http://www.kuranmeali.org/18/kehf_suresi/43.ayet/kurani_kerim_ mealleri.aspx (Date of access: 12.06.2017).

Quran-Talak (2017) http://www.kuranmeali.org/kuran/talak-suresi/ayet-3/2-diyanetisleri-meali.aspx (Date of access: 14.06.2017).

Quran-Tevbe (2017) http://www.kuranmeali.org/kuran/tevbe-suresi/ (Date of access: 13.06.2017).

Rachels, J. (1975). Active and Passive Euthanasia. The New England Journal of Medicine. 292(2). 78-80.

Ratanakul, P. (2009). Bioethics in Thailand: An Update. Asian Bioethics Review. 1(1). 47-53.

Safyan, A. (2011). A Call for International Regulation of the Thriving Industry of Death Tourism, Loyola of Los Angeles International and Comprehensive Law Review. 33(287). 287-319.

Sayid, M., D. (1983). Euthanasia: A Comparison of the Criminal Laws of Germany, Switzerland and the United States. Boston College International and Comparative Law Review. 6(2). 533-562.

Scherer, J., M. and Simon, R., J. (1999). Euthanasia and the Right To Die: A Comparative View. Rowman \& Littlefield. USA. 
Seale C. (2009) Legalisation of The Euthanasia or Physician- Assested Suicide: Survey of Doctors' Attitudes. Palliative Medicine. 23(3):205-212.

Shoval, N. and Isaacson, M. (2007). Sequence Alignment as A Method for Human Activity Analysis in Space And Time. Annals of the Association Of American Geographers. 97(2). 282-297.

Shuriye, A., O. (2001). Ethical and Religious Analysis On Euthanasia, Special Issue on Science and Ethics in Engineering. IIUM Engineering Journal. 12(5). 209-211.

Sicart, C. (2016). An Essay on Redefining Tourism. An Epistemological Approach and Town and Country Planning for Tourism, European Journal of Tourism Research. 14. 123-126.

Smets, T., Bilsen, J., Cohen, J., Rurup, M. L. and Deliens, L. (2010). Legal Euthanasia in Belgium: Characteristics of All Reported Euthanasia Cases. Medical Care. 48(2). 187-192.

Stajano, A. (2015). Only Love Remains: Lessons from the Dying on the Meaning of Life-Euthanasia or Palliative Care? Clairview Books. Great Britain.

Sümer, N. (2015). Dinlerin Intihar Olgusuna Bakışı. Yayınlanmamış Doktora Tezi. Ankara Üniversitesi Sosyal Bilimler Enstitüsü. Ankara.

Symeonidou-Kastanidou, E. (2006). Euthanasia in The Domestic Legal System of Greece. Revue Hellenique de Droit International. 59(1). 495.

The Richest. (2016). [http://www.therichest.com/rich-list/most-influential/10-countrieswhere-euthanasia-and-assisted-suicide-are-legal/] (Date of access: 24.11.2016).

Theobald, W., F. (2005). Global Tourism. Third Editon. Elsevier Science. USA.

Theofanidis, D. and Mecek, F. (2016). Euthanasia: A Healthcare Debate from A GreekTurkish Perspective. International Journal. 9(1). 321.

Tribe, J. (2009). Philosophical Issues in Tourism. Channel View Publications. USA.

Tsomo, K., L. (2006). Out of the Shadows: Socially Engaged Buddhist Women. In Sakyadhita International Conference on Buddhist Women (8th). Sri Satguru Publications (a division of Indian Books Centre).

Tuan, Y., F., T. (1974). A Study of Environmental Perception. Attitudes, and Values. Columbia University Press. New York.

United Nations World Tourism Organization. (2016). Compilation of UNWTO Recommendations, 1975-2015. Madrid. Spain.

Urry, J. (1992). The Tourist Gaze "Revisited". American Behavioral Scientist. 36(2). 172-186.

Urry, J. and Larsen, J. (2011). The tourist gaze 3.0. Sage. London.

Varadarajan, R., Freeman, R., A. and Parmar, J., R. (2016). Aid-in-Dying Practice in Europe and The United States: Legal and Ethical Perspectives for Pharmacy. Research in Social and Administrative Pharmacy. 12. 1016-1025.

Vilela, L., P. and Caramelli, P. (2009), 'Knowledge of the Definition of Euthanasia: Study with Doctors and Caregivers of Alzheimer's Disease Patients, Revista da Associacao Medica Brasileira. 55(3). 263-267.

Von Schullern, H. (1911). Fremdenverkehr und Volkswirtschaft. Jahrbuch fur National Economie und Statistik. Jena.

Williams, A., M., and Hall, C., M. (2000). Tourism and Migration: New Relationships Between Production and Consumption. Tourism Geographies. 2(1). 5-27. 
Williams, J., R. (2015), Medical Ethics Manual 3rd Edition, World Medical Association, France.

World Health Organization. (2014). Preventing Suicide: A Global Imperative. [http://apps.who.int/iris/bitstream/10665/131056/1/9789241564779_eng.pdf] (Date of Access: 22.04.2017).

World Health Organization. (2016). Definition of Palliative Care. [http://www.who.int/cancer/palliative/definition/en/] (Date of access: 26.04.2016).

World Medical Association. (1949). International Code of Medical Ethics. [http://www.wma.net/en/30publications/10policies/c8/index.html] (Date of access: 26.04.2017).

World Medical Association. (1981). Declaration of Lisbon on the Rights of the Patient. [http://www.wma.net/en/30publications/10policies/14/]. (Date of access: 26.04.2017).

World Medical Association. (1987). Declaration on Euthanasia. [http://www.wma.net/en/30publications/10policies/e13/]. (Date of access: 26.04.2017).

World Medical Association. (1992). Statement on Physician-Assisted Suicide. [http://www.wma.net/en/30publications/10policies/p13/]. (Date of access: 26.04.2017).

World Medical Association. (2006). International Code Of Medical Ethic [https://www.wma.net/policies-post/wma-international-code-of-medical-ethics/] (Date of access: 26.04.2017).

World Tourism Organisation (WTO). (1995). Collection of Tourism Expenditure Statistics (Technical Manual No: 2). Madrid. Spain.

World. (2015). [https://world.wng.org/2015/07/colombia opens its doors to euthanasia] 07.07.2015. (Date of access: 28.11.2016).

Yiğit, Y. (2000). İslam Ceza Hukukuna Göre Ötanazi ve Hukuki Sonuçlarının Değerlendirilmesi, İslamî Araştırmalar Dergisi. 36(2). 337-349.

Yuan, S. and McDonald, C. (1990). Motivational Determinates of International Pleasure Time. Journal of Travel Research. 29(1). 42-44.

Zaritsky J. (2007). The Suicide Tourist (Documentary). CTV. Toronto. 